\title{
Elements of Advocacy in Transport Policy Formulation
}

\author{
Artur Carlos de Morais \\ Professor of Faculty of Civil Engineering \\ University Center Estácio of Brasília, Brazil \\ Anísio Brasileiro de Freitas Dourado \\ Rector of Federal University of Pernambuco \\ Joaquim Jose Guilherme Aragão \\ Professor of Faculty of Civil Engineering \\ University of Brasília, Brazil \\ Yaeko Yamashita \\ Professor of Faculty of Civil Engineering \\ University of Brasília, Brazil
}

\begin{abstract}
Public transport policies appear to be extremely important in almost every aspect of the life of a community and a major component of the economy. However, their viability is not conditioned only by technical aspects affecting engineering problems or economic viability, as there are other components that contribute to the decision of the public official to act or not to act. The failure in the implementation of viable transport projects, technically and economically, can often be attributed to the lack of these external components to the engineering environment. One such component occurs in the arena of disputes and negotiations between actors. This paper presents a proposal for actions and resources to work on the political viability of transport projects in addition to the technical and economic justification. It draws its theoretical basis from the Policy Cycle model, which defines the decision-making steps and advocacy, along with the actions and resources that make it possible to convince the stakeholders involved. The proposed test was performed for two public policy projects, a public transport operation project and a change in traffic safety legislation. The first and third phases of the Policy Cycle forecast $\mathbf{1 0 0 \%}$ of the items for advocacy action, the barriers to policy, actions to overcome these barriers, and resources that support these actions. In the second phase, the barriers and actions were also $100 \%$ forecast, but for the resources that support the forecast actions were low, about $33 \%$ for the transport project and $22 \%$ for the draft amendment of the legislation.
\end{abstract}

Keywords: Advocacy, Stakeholders, Policy Cycle Model, Transport Policy,

\section{INTRODUCTION}

Public policies play an important role in determining social justice, political freedoms and civil freedoms, in the long-term interests of the environment and the well-being of people in general. However, on many occasions, public policy is formulated by members of the dominant players of powerful social groups. Most often, access and the persuasiveness of the decision makers are restricted to these groups, who use the situation to impose their interests, which are not always in line with the needs of marginalized people, in decision making.

There is a need to include the voices of those people excluded from decision-making processes. Therefore, organized groups take actions seeking to defend the interests of these marginalized groups and to generate in those citizens the ability to claim. These actions are called advocacy. 
According to Mansfield (2010), the preparation of an action plan is an important step in advocacy and it should contain the following cycle:

I. Identify the desired changes, the time to reach them and quantitative or qualitative indicators to evaluate the result of the action;

II. Identify the stakeholders (allies and opponents) and the degree of influence that each has on the decision;

III. Identify the target actors of the advocacy action; and

IV. Define strategy.

To develop an advocacy action strategy, Morais (2012) identified the need to know certain elements: i) what difficulties (barriers) need to be overcome to achieve the goal? ii) what needs to be done to overcome these difficulties, what actions and what resources should be used in these actions?

The actions and resources to be used are common to all advocacy practice regardless of public policy type, and can vary in intensity of use and positive outcomes from one policy to another. However, the barrier element may be peculiar to each policy.

So, to develop an advocacy action plan on public policy it is necessary to identify the elements regarding barriers, actions and resources. Therefore, the purpose of this article is to present the process of identifying these elements and test projects relating to public transport policies. Therefore, the article is divided into seven sections; after this introduction to the paper, the methodology will be presented. In the third section, the phases of the formulated model, the Policy Cycle, will be presented and an analysis of the public policies to be considered in this work. In the same section a text on advocacy is developed, in addition to its definition, what are the practices and processes and the elements of the actions and resources to actions are presented, since they are inherent in advocacy activity. Section 4 aims to identify the element of barriers, and in the fifth section the tests to validate the three elements will be presented. This validation is achieved through a survey of 8 transportation projects through interviews with their managers. This section will present tables showing the hierarchy of positive results of actions and resources for each type of barrier.

In section 6, this hierarchy will be validated in two projects relating to transport policies, a local project in Brasilia concerning public transport operation of passengers and national project for the approval of a law that regulates traffic behaviour. Finally, the final considerations will be presented.

\section{METHODOLOGY}

For the preparation of the advocacy action plan for the implementation of a public transport policy, the steps to be followed are described below:

Step 1: Identification of the components of advocacy that will proceed by reading papers published in the scientific literature on public transport policies as well as advocacy and processes to be described in detail in sections 3 and 4 .

Step 2: Quantify the occurrences of the relevant elements in step 1 and their positive results. Therefore, we identified two steps to be performed, the first, to choose a set of transportation projects that will be used as the basis for quantifying the elements and in a second phase, to prepare a questionnaire and apply it to the management of the projects.

Among the wide range of potential transportation projects to be used as a starting point to verify the occurrence of the elements, the choice of projects was made according to the 
following criteria:

I. Ease of access to documents on the project;

II. Ease of contact with coordinators and managers of the projects; and

III. The availability of engineers and managers of the projects to participate in research.

The questionnaires were developed and implemented using the website www.surveymonkey.com, a paid service for conducting research. Each questionnaire creates its own link sent by email to the corresponding respondent for the project.

The questionnaires were completed in three stages, with direct questions where the respondent, the project coordinator, has as response the elements of advocacy options. The first questionnaire identifies the difficulties; the second, the actions and the third, material support. The questions are referenced to the stages of the process of developing a public policy as considered using the Public Policy Cycle model, i.e. the agenda, the development of options and implementation. The model will be presented in the next section.

Quantification of the variables will be made using the cumulative frequency with which they occur and the ranking is created from the respondents' answers on which elements were considered to provide positive effects.

Step 3: To test the consistency of the elements identified and also the results, the same questionnaire will be applied to the public policy projects and then compared through tables using the ranking created in the previous step.

\section{ADVOCACY, CONCEPTS AND PRACTICES (STEP 1)}

Before dealing with advocacy, it is necessary to make some comments on the wording of the model and analysis of public policies that will be considered in this work, the public policy cycle model. This model is seen as a chain of stages, a deliberative cycle consists of stages in a dynamic process (Souza, 2006). Some authors differ in their studies when they indicate the phases that make up the public policy cycle, but four of them are always present and the first two are considered in this work:

I. Agenda setting: mainly comprises the identification of the problem and the recognition of the need to solve it, that is, the process in which the public manager recognizes the existence of a problem, a demand from society that should be addressed through State intervention;

II. Development of options: selection of proposals for the solution of the problem and formalization in law (where necessary);

III. Implementation: creation of instruments to operationalize the policy and its implementation; and

IV. Evaluation: impact of policy implementation and correct directions.

\section{Concept of Advocacy}

As Libardoni stated (2000), the term advocacy is derived from the Latin word "advocare", which means helping someone who is in need. Its origin is closely linked to legal issues, the defence of clients by legal process. In the mid-1960s and early 1970s, the civil rights movement in the US expanded the use of the term, taking the concept of justice in three new directions. In addition to the legal defence of the individual, there is the defence of the interests of marginalized groups, proactive measures to change the rules in defence of the environment, and to defend against public abuses of power (Brelaz and Alves, 2011). 
Some authors in Brazilian literature, Libardoni (2000), Feix (2004) and Azevedo (2003) and the international Gordon (2002), Negarendeh et al. (2006), O`Flynn (2009), Nukuro (2000), Christoffel (2000) and Thackeray and Hunter (2010), to name a few, understand the term advocacy to mean the politics and process of transformation of values and beliefs for improving the awareness and knowledge of citizens, for the support of a person's rights and the defence of a cause that results in influence on the decision-making power on issues of interest.

Advocacy also has the goal of creating the conditions for citizens to represent themselves or speak for themselves in conflicts relating to political changes. This objective is given the name of empowerment and is considered of great importance in advocacy activity (Azevedo, 2003).

Therefore, it is clear that advocacy, in essence, is an action of defence of citizens' interests, even if the citizen does not recognize that particular fact concerning him or her. Advocacy requires the responsible agent to take actions to generate a transformation of people's values and beliefs in order to improve the awareness and knowledge of citizens, so that it can help in the action to claim their rights.

The targets of the action are the agents responsible for decision-making on public policy, and the goal of advocacy is to promote the greater participation of society in the formulation and implementation of laws and public policies, directly or through representatives, so that influencing decision-makers in the decision-making process can make positive changes in people's lives.

This terminology allows us to understand that the activity of advocacy carries with it the idea of fighting for more and better rights, for a more dignified quality of life, the democratization of decision-making. It is, in short, a process of change. This change can occur at two levels: personal and political.

Personal is directly linked to the empowerment of the event, i.e., is the effect that the work of advocacy has on citizens, turning them into active agents of change. While political change is related to the outcome of the advocacy work, which aims at changing legislation, putting a specific public policy on the agenda of priorities, and the implementation of government programmes and projects in different areas of government action. Thus, the advocacy actions are likely to be directed to the staff of different spheres of government: executive, legislative and judicial.

\section{Practices and Processes of Advocacy}

The advocacy of activities may include public and private (lobbying) campaigning through awareness raising, use of research, documentation and media to influence decision makers (Kelly, 2002; Efroymson, 2006). Lobbying and campaigning are sometimes treated as synonymous with advocacy but are distinct practices by the members of an advocacy process and may occur alone or in complementary forms. The basic differences identified in the literature are summarized in Table 1:

Table 1: Differences between campaigning and lobbying

\begin{tabular}{|c|c|c|}
\hline & Campaigns & Lobbying \\
\hline Participation & Greater number of participants & $\begin{array}{c}\text { Either smaller number of } \\
\text { participants }\end{array}$ \\
\hline Relationship & Contact mediated by media & Direct contact \\
\hline Approach Form & A public visibility event & A relatively private process \\
\hline Language & Simplified messages & More detailed messages \\
\hline
\end{tabular}


The campaign is an activity that enables the publicizing of the goal of the advocacy action, developed with and for a large number of people. The expected results of the campaign are to raise the awareness of decision makers and the involvement of a larger number of people and organizations in the desired change.

The media is a great ally for the success of campaigns because not all citizens or organizations engaged in an advocacy activity have direct contact with the authorities with decision-making power. In this way, the media is a powerful tool to reach governments and make them work for the desired changes. However, the news coverage is not objective regarding advocacy, but the effect of this media cover (Efroymson, 2006; Gibson, 2010).

The more approaches made, the more there is a chance that an authority becomes aware and pays attention to the subject, and also the population is informed and worry about it. Therefore, the media coverage reaches two system poles: the decision maker and the citizen. The story being told by the advocate should be appealing to publishers, and journalists are sensitized to tell it. For this to occur, the agents of advocacy conduct research and provide documentation to give consistency to the information and strengthen its objectives (Kelly, 2002; Efroymson, 2006).

In addition to using the media, there are other ways to develop an advocacy campaign, such as the use of telecommunication technologies (Thackeray and Hunter, 2010); public hearings (Peterman, 2004; Gomm et al., 2006); motions (Christoffel, 2000) and public mobilization (Christoffel, 2000; Gomm et al., 2006).

In opposition to the advertising campaign, the lobby is more related to direct contact with members of the legislature and executive to propose changes, to create or oppose legislation. It is performed by a smaller group of participants, the contact is more direct between the advocacy agent and public agents and the language is more detailed. Due to the direct contact, there may be more detail than is desirable.

Some techniques are used as lobbying actions: letters, meetings, phone calls, petitions, etc. (Gomm et al., 2006). As in the campaign, lobbyists also use statistics and documentation as advocacy strategies to persuade decision makers. Advocacy research should be directed towards the goal, that is, do not do research to increase knowledge but to support and inform about a particular topic and provide evidence on the need for change.

According to Efroymson (2006), the search can be made by advocacy agents or make use of documentation (second-order data) to obtain information needed to convince public officials about the importance of the issue, respond to an objection to the change proposed or demonstrate popular support for the issue.

Letters, phone calls and petitions are easier and quick methods for lobbying, representing advocacy at its most basic level, communication: individuals or groups sending messages in order to influence others (Thackeray and Hunter, 2010). However, these are actions can lead to poor results since many people in positions of power have assistants who read their emails and letters, selecting subjects and summarizing them, and are not always accessible to phone calls. Of the three, petitions may be the method giving the best chance of gaining the attention of the decision maker, as through the signatures it can be shown to the agent that the subject under discussion is supported by a large part of the population. 
However, meeting (face-to-face) provides the best results for lobbying because this action assumes access to the decision maker by a direct route and, as Dye stated (2009), access to authority is a factor bringing the influence of a group in the decision-making. A direct encounter may explain in more detail to the decision-making agent the benefits that the defended proposition can generate. It is also an opportunity to give voice to community leaders who support and require the policy advocated and put them face to face with the decision makers.

The campaigning and lobbying techniques and the resources to support them are summarized in Tables 2 and 3, respectively.

Table 2: Actions

\begin{tabular}{|c|c|c|c|c|}
\hline Element & Technical & Description & Action Type & Description \\
\hline \multirow{7}{*}{ Actions } & \multirow{4}{*}{ Campaign } & \multirow{4}{*}{$\begin{array}{l}\text { Public event in order to } \\
\text { reach a large number of } \\
\text { people, characterized by } \\
\text { generic information and } \\
\text { summarizing the benefits } \\
\text { of the demand }\end{array}$} & Media & News in the media \\
\hline & & & Public hearings & $\begin{array}{l}\text { Use of lectures, } \\
\text { seminars, workshops } \\
\text { to disseminate demand }\end{array}$ \\
\hline & & & Motions & $\begin{array}{l}\text { Action } \\
\text { parliamentarians in } \\
\text { favour of demand }\end{array}$ \\
\hline & & & $\begin{array}{l}\text { Public } \\
\text { mobilizations }\end{array}$ & $\begin{array}{l}\text { Events in public places } \\
\text { such as streets and } \\
\text { squares to demand the } \\
\text { disclosure order }\end{array}$ \\
\hline & \multirow[b]{3}{*}{ Lobby } & \multirow{3}{*}{$\begin{array}{l}\text { Private event } \\
\text { characterized by the small } \\
\text { number of people } \\
\text { participating, where there } \\
\text { is the possibility to detail } \\
\text { the positive aspects of the } \\
\text { demand and necessarily } \\
\text { the presence of } \\
\text { beneficiaries and / or } \\
\text { mediators and decision- } \\
\text { makers and/or directors }\end{array}$} & $\begin{array}{l}\text { Telecommunication } \\
\text { technologies }\end{array}$ & $\begin{array}{l}\text { Use of phone calls, and } \\
\text { email for mobilization } \\
\text { and persuasion }\end{array}$ \\
\hline & & & Hearings & Scheduled meetings \\
\hline & & & Meetings & Unscheduled meetings \\
\hline
\end{tabular}

Some elements are considered when carrying out these actions and are inserted in Table 3.

Table 3: Instruments in support of advocacy actions

\begin{tabular}{|c|l|l|}
\hline \multirow{2}{*}{ Element } & \multicolumn{1}{|c|}{$\begin{array}{c}\text { Resource } \\
\text { Types }\end{array}$} & \multicolumn{1}{c|}{ Description } \\
\hline \multirow{3}{*}{$\begin{array}{c}\text { Resources to } \\
\text { support actions }\end{array}$} & Statistics & Data supporting the positive aspects of the demand \\
\cline { 2 - 3 } & Examples & Similar demands that were successful \\
\cline { 2 - 3 } & Statements & $\begin{array}{l}\text { Information specialists that contribute to the demonstration } \\
\text { of the demand legitimacy }\end{array}$ \\
\cline { 2 - 3 } & Releases & $\begin{array}{l}\text { Materials made with the positive demand and distributed to } \\
\text { the media }\end{array}$ \\
\hline
\end{tabular}

TYPES OF BARRIERS TO ADVOCACY IN TRANSPORT PUBLIC POLICY (STEP 1 CONTINUED) A barrier is an obstacle that prevents a particular claim being implemented or causes delays in its implementation, according to May et al. (2001). These authors claim that barriers can be rigid or flexible, positive or negative. The rigidity of the barrier is not understood as being 
unsurmountable, but requires greater allocation of resources for longer periods to be overcome.

Barriers are considered positive when one of the objectives of the strategy restricts the ability of public policy to achieve other goals. This occurs, for example, with environmental restrictions. Its imposition may well improve the benefits that policy will bring to society. Negative, in turn, can cause excessive delays and costs in its application.

As this study was conducted in relation to transport policy, research was carried out in the literature areas of political science, transportation and advocacy. In order to identify the existence of direct references to the types of barriers and the interpretation of the texts identifying them, the result is shown in Table 4. Note that the table is not exhaustive. 
Table 4: Description of the barriers identified in the literature

\begin{tabular}{|c|c|}
\hline Authors & Barriers \\
\hline May et al., 2001 & $\begin{array}{l}\text { "Legal and institutional: lack of legal powers to implement a particular } \\
\text { measure, and legal responsibilities which are split between agencies, limiting } \\
\text { the ability of the city authority to implement the affected measure; } \\
\text { Financial: budget restrictions limiting the overall expenditure on the strategy, } \\
\text { financial restrictions on specific measures, and limitations on the flexibility } \\
\text { with which revenues can be used to finance the full range of measures; } \\
\text { Political and cultural aspects: lack of political or public acceptance of a } \\
\text { measure, restrictions imposed by pressure groups, and cultural attributes, } \\
\text { such as attitudes to enforcement, which influence the effectiveness of } \\
\text { measures." }\end{array}$ \\
\hline Subaris, 2006 & Political game of interest groups \\
\hline Gomm et al., 2006 & $\begin{array}{l}\text { "Since reform typically involves changing the status quo with opposition } \\
\text { coming from governments, industry and community interest groups." }\end{array}$ \\
\hline Lindb & "There are most problems to be solved that budget to address them." \\
\hline $\begin{array}{l}\text { Huitema and Meijerink, } \\
\qquad 2010\end{array}$ & $\begin{array}{l}\text { "This is why, in this special issue, we explore the role of 'policy entrepreneurs' } \\
\text { in instigating, implementing, and sometimes blocking policy change. Insight } \\
\text { into their role in stimulating policy change is crucial if we want to develop a } \\
\text { more systematic approach to adaptability that is less dependent on shock } \\
\text { events to trigger transitions." }\end{array}$ \\
\hline Souza et al., 2006 & $\begin{array}{l}\text { Political and party differences; } \\
\text { Administrative and bureaucratic difficulties in the application of resources; } \\
\text { Political interference in the pre-election period; and } \\
\text { Delay in the arrival of resources. }\end{array}$ \\
\hline Ieromonachou et al., 2007 & $\begin{array}{l}\text { "This is still reflected by the fact that public opposition towards the scheme is } \\
\text { still quite high after twenty years and so many completed road projects." } \\
\text { "The pioneering niche of Bergen emerged due to particular circumstances, that } \\
\text { developed partner motivations, the most important of which was a resource } \\
\text { constraint - the need to raise revenue to accelerate the building of much } \\
\text { needed road infrastructure." } \\
\text { "The biggest issue that the city of Bergen faced was obtaining initial approval } \\
\text { for the Toll Ring system, as Norwegians already bore heavy taxes including } \\
\text { those for road transport... People argued that road building was a government } \\
\text { responsibility, thus, the government should provide the funds for it." } \\
\text { "Perhaps most importantly were the presence of strong political leadership } \\
\text { from both the elected representatives and the officials of the County Council } \\
\text { who campaigned many years for the scheme." }\end{array}$ \\
\hline Ubbels and Verl & $\begin{array}{l}\text { "Despite the fact that politicians and the public regard transport problems as } \\
\text { very urgent and important, people do have concerns about road pricing, often } \\
\text { resulting in low acceptance levels." }\end{array}$ \\
\hline Han, 2010 & $\begin{array}{l}\text { "It is common in both developed and less-developed countries that funds for } \\
\text { building urban public transport infrastructure tend to be scarce." } \\
\text { "Policies on car ownership, known to researchers as demand management } \\
\text { tools, are likely to be unpopular with the public and are probably unfair." }\end{array}$ \\
\hline Palma and Lindsey, 2006 & $\begin{array}{l}\text { "Legal restrictions currently prevent differentiation of tolls sufficiently to price } \\
\text { all trips at marginal social cost." } \\
\text { "Acceptability barriers pose a significant barrier to tolling generally." }\end{array}$ \\
\hline
\end{tabular}

The barriers found in the literature and from the authors' own experience were grouped as follows:

I. Legal: legal impediments that make it difficult to meet the demand.

II. Budget: financial difficulties of the government to meet the demand.

III. Auto-financing: Demand have difficulties financial sustainability, require public contribution to be viable.

IV. Infrastructural: the need for other policies or projects to meet the demand.

V. Policy: Resistance of actors that have different demand objectives, lack of political godfather or weak political godfather. 
VI. Technology: No technology available on the market that meets the demand.

As described above, to achieve the advocacy goals, there is the need to overcome barriers and, therefore, some practices are implemented.

\section{QUANTIFY AND PRIORITIZE OCCURRENCE OF ELEMENTS OF ADVOCACY ACTION (STEP 2)}

This section will present the quantification of occurrences of the elements and the positive results. The projects that were used to create the ranking of advocacy elements are listed in Table 5; questionnaires were sent to their managers.

Table 5: Description of the objectives of the chosen projects

\begin{tabular}{clc}
\hline Project & \multicolumn{1}{c}{ Objective } & Situation \\
\hline A & $\begin{array}{l}\text { The development and implementation of a system } \\
\text { to evaluate transport programmes } \\
\text { Adopt new taxi fare calculation methodology } \\
\text { Development and implementation of a concession } \\
\text { granting process for passenger road transport at } \\
\text { the federal level }\end{array}$ & In Implementation \\
D & $\begin{array}{l}\text { Development and implementation of process of } \\
\text { granting aviators a terminal grant }\end{array}$ & Implemented \\
E & $\begin{array}{l}\text { Facilitate international air traffic at regional } \\
\text { airport terminals }\end{array}$ & Implemented \\
F & $\begin{array}{l}\text { Approve legislation } \\
\text { Development and delegation model of deployment } \\
\text { and management for road transport passengers at } \\
\text { the municipal level }\end{array}$ & Partially Implemented \\
G & Identify passenger costs for subsidies & In Implementation \\
\hline
\end{tabular}

The questionnaires indicated the elements found in the studied works and respondents were asked to mark which were present in their respective projects and which actions and resources used generated positive results.

In the answers to the first questionnaire, the sum of the events in the three phases (agenda for the elaboration of options and implementation) shows that the "resistance of actors" barrier is the most common difficulty encountered in the projects, with 18 responses, with the triple the occurrences of the second perceived barriers, "need for other projects or policies to meet the demand" and "other" six each. Project "B" was the only one that did not present "resistance of actors" in any of the surveyed phases. The cumulative frequency of responses, aggregated over the three phases surveyed is presented in Table 6.

Table 6: Number of identified barriers

\begin{tabular}{lc}
\hline \multicolumn{1}{c}{ Barriers } & Occurrences \\
\hline Resistance of actors who have different demand goals & 18 \\
Need for other policies or projects to meet the demand & 6 \\
Demand does not have financial sustainability & 3 \\
Legal impediments that make it difficult to meet the demand & 3 \\
Financial difficulties of the government to meet the demand & 3 \\
Lack of a political godfather & 2 \\
Weak political godfather & 2 \\
Lack of technology to meet the demand & 1 \\
\hline
\end{tabular}

The barriers that were not mentioned in the answers are not shown in Table 6. Following the results of the first questionnaire, the second was prepared, whose results are presented below. 
In this second phase of the questionnaires, the actions taken in order to overcome the barriers related to the first questionnaire were identified. Out of the eight completed questionnaires in the first step, in the second phase only the questionnaire for project "G" went unanswered. Therefore, for this phase the sample was seven projects.

The results of the questionnaires show that the action "scheduled meeting" was the most frequently performed and the one with the best aggregate result in the three phases with 29 responses. The results for the number of actions that were positive to overcome the barriers in aggregate values in the three phases are presented in Table 7.

Table 7: Quantitative of the actions performed and positive results

\begin{tabular}{lcc}
\hline \multicolumn{1}{c}{ Action } & Number executed & Positive results \\
\hline Scheduled meetings & 29 & 22 \\
Lectures, seminars, workshops and public & 17 & 8 \\
hearings & 17 & 5 \\
Contact through phone, email and social & & \\
networks & 7 & 6 \\
Non-scheduled meetings & 4 & 1 \\
News in the media & & \\
\hline
\end{tabular}

The actions "Lectures, seminars, workshops and public hearings" and "Contact through phone calls, email and social networks" were in second place in terms of achievements, with 17 events each, but with different results. The second underperformed with five positive results. This performance is explained by the fact that many people in positions of power have assistants who read their emails and letters, selecting subjects and summarizing them and are not always accessible to phone calls.

The values of the frequencies of occurrence of each action performed disaggregated by developing a public policy phase shows that with the exception of the actions "parliamentary action in favour of demand" and "events in public places such as streets and squares" - which were not carried out in any phase of the projects and "news in the media" that only occurred in the implementation phase, all the others were achieved at all the stages studied.

The third questionnaire was intended to identify the resources used in carrying out the actions. Just as in the second questionnaire, the sample contained seven projects.

The resources most used in all three phases studied were "data supporting the positive aspects of the demand", followed by "information specialists that contribute to the demonstration of the demand legitimacy", "similar demands were successful", and less used was "materials made with the positive demand and distributed to the media".

Regarding resources used for actions that produced positive results (Table 8) show that there was no difference in the results. In drafting the options, the resources that were most used to produce positive results with the best performance in the ratio of four positive results for thirteen uses were the resource "data supporting the positive aspects of the demand".

Table 8: Quantitative of resources used and positive results

\begin{tabular}{lcc}
\hline \multicolumn{1}{c}{ Resources to support actions } & Used & Positive results \\
\hline Data supporting the positive aspects of the & 58 & 34 \\
demand & & 25 \\
Information from specialists & 41 & 17 \\
Similar demands that were successful & 21 & 2 \\
Materials prepared for the media & 10 & \\
\hline
\end{tabular}




\section{Ranking of Constituents Advocacy Elements}

With the results of these questionnaires it was possible to elaborate a ranking of the actions and resources to be employed in overcoming the barriers as in tables 9 (schedule), 11 (development of options) and 12 (deployment).

Table 9: Priority actions and resources to overcome the barriers in the inclusion phase in public

\begin{tabular}{|c|c|c|c|c|}
\hline & \multirow[b]{2}{*}{ Priority } & \multicolumn{2}{|c|}{ agenda } & \multirow[b]{2}{*}{ Resource } \\
\hline Barriers & & Action & Priority & \\
\hline \multirow{13}{*}{ Resistance of actors } & \multirow{3}{*}{1 st } & \multirow{3}{*}{ Scheduled meetings } & $1^{\text {st }}$ & $\begin{array}{l}\text { Data supporting the positive aspects of the } \\
\text { demand }\end{array}$ \\
\hline & & & $2^{\text {nd }}$ & Information from specialists \\
\hline & & & $3^{\text {rd }}$ & Similar demands that were successful \\
\hline & \multirow{4}{*}{ 2nd } & \multirow{4}{*}{$\begin{array}{l}\text { Lectures, seminars, } \\
\text { workshops and public } \\
\text { hearings }\end{array}$} & $1^{\text {st }}$ & $\begin{array}{l}\text { Data supporting the positive aspects of the } \\
\text { demand }\end{array}$ \\
\hline & & & $2^{\text {nd }}$ & Similar demands that were successful \\
\hline & & & 3 rd & Information from specialists \\
\hline & & & 4th & Materials prepared for the media \\
\hline & \multirow{3}{*}{$3 r d$} & \multirow{3}{*}{$\begin{array}{l}\text { Contact through phone, } \\
\text { email and social } \\
\text { networks }\end{array}$} & 1 st & $\begin{array}{l}\text { Data supporting the positive aspects of the } \\
\text { demand }\end{array}$ \\
\hline & & & 2nd & Information from specialists \\
\hline & & & $3 r d$ & Similar demands that were successful \\
\hline & \multirow{3}{*}{ 4th } & \multirow{3}{*}{$\begin{array}{l}\text { Non-scheduled } \\
\text { meetings }\end{array}$} & 1 st & $\begin{array}{l}\text { Data supporting the positive aspects of the } \\
\text { demand }\end{array}$ \\
\hline & & & 2nd & Information from specialists \\
\hline & & & 3 rd & Similar demands that were successful \\
\hline $\begin{array}{l}\text { Lack of government } \\
\text { resources }\end{array}$ & Unique & Scheduled meetings & - & Not identified \\
\hline \multirow{2}{*}{$\begin{array}{l}\text { Demand does not } \\
\text { have financial } \\
\text { sustainability }\end{array}$} & \multirow{2}{*}{ Unique } & \multirow{2}{*}{ Scheduled meetings } & 1st & $\begin{array}{l}\text { Data supporting the positive aspects of the } \\
\text { demand }\end{array}$ \\
\hline & & & 2nd & Information from specialists \\
\hline \multirow{2}{*}{$\begin{array}{l}\text { Need for other } \\
\text { policies }\end{array}$} & \multirow[t]{2}{*}{ Unique } & \multirow[t]{2}{*}{ Scheduled meetings } & 1st & $\begin{array}{l}\text { Data supporting the positive aspects of the } \\
\text { demand }\end{array}$ \\
\hline & & & 2nd & Information from specialists \\
\hline
\end{tabular}

Table 10: Priority actions and resources to overcome the barriers in the development of options

\begin{tabular}{|c|c|c|c|c|}
\hline \multicolumn{5}{|c|}{ phase } \\
\hline Barriers & Priority & Action & Priority & Resource \\
\hline \multirow{3}{*}{ Resistance of actors } & 1 st & Scheduled meetings & Unique & $\begin{array}{l}\text { Data supporting the positive aspects of the } \\
\text { demand }\end{array}$ \\
\hline & 2nd & $\begin{array}{l}\text { Lectures, seminars, } \\
\text { workshops and public } \\
\text { hearings }\end{array}$ & Unique & $\begin{array}{l}\text { Data supporting the positive aspects of the } \\
\text { demand }\end{array}$ \\
\hline & $3 r d$ & $\begin{array}{l}\text { Non-scheduled } \\
\text { meetings }\end{array}$ & Unique & $\begin{array}{l}\text { Data supporting the positive aspects of the } \\
\text { demand }\end{array}$ \\
\hline $\begin{array}{l}\text { Lack of government } \\
\text { resources }\end{array}$ & Unique & scheduled meetings & Unique & Materials prepared for the media \\
\hline $\begin{array}{l}\text { Demand does not have } \\
\text { financial sustainability }\end{array}$ & Unique & scheduled meetings & Unique & Not identified \\
\hline \multirow{3}{*}{ Weak political godfather } & 1 st & scheduled meetings & Unique & Information from specialists \\
\hline & \multirow[t]{2}{*}{ 2nd } & \multirow[t]{2}{*}{$\begin{array}{l}\text { Non-scheduled } \\
\text { meetings }\end{array}$} & 1 st & $\begin{array}{l}\text { Data supporting the positive aspects of the } \\
\text { demand }\end{array}$ \\
\hline & & & 2nd & Information from specialists \\
\hline
\end{tabular}


Table 11: Priority actions and resources to overcome the barriers in the implementation phase

\begin{tabular}{|c|c|c|c|c|}
\hline Barriers & Priority & Action & Priority & Resource \\
\hline \multirow{12}{*}{ Resistance of actors } & \multirow{3}{*}{$1 \mathrm{st}$} & \multirow{3}{*}{ Scheduled meetings } & $1^{\text {st }}$ & $\begin{array}{l}\text { Data supporting the positive aspects of the } \\
\text { demand }\end{array}$ \\
\hline & & & $2^{\text {nd }}$ & Information from specialists \\
\hline & & & $3^{\text {rd }}$ & Similar demands that were successful \\
\hline & \multirow{3}{*}{ 2nd } & \multirow{3}{*}{$\begin{array}{l}\text { Non-scheduled } \\
\text { meetings }\end{array}$} & $1^{\text {st }}$ & $\begin{array}{l}\text { Data supporting the positive aspects of the } \\
\text { demand }\end{array}$ \\
\hline & & & $2^{\text {nd }}$ & Information from specialists \\
\hline & & & $3^{\text {rd }}$ & Similar demands that were successful \\
\hline & \multirow{3}{*}{$3 r d$} & \multirow{3}{*}{$\begin{array}{l}\text { Lectures, seminars, } \\
\text { workshops and } \\
\text { public hearings }\end{array}$} & $1^{\text {st }}$ & $\begin{array}{l}\text { Data supporting the positive aspects of the } \\
\text { demand }\end{array}$ \\
\hline & & & $2^{\text {nd }}$ & Similar demands that were successful \\
\hline & & & $3^{\text {rd }}$ & Information from specialists \\
\hline & \multirow{3}{*}{4 th } & \multirow{3}{*}{$\begin{array}{l}\text { Contact through } \\
\text { phone, email and } \\
\text { social networks }\end{array}$} & $1^{\text {st }}$ & $\begin{array}{l}\text { Data supporting the positive aspects of the } \\
\text { demand }\end{array}$ \\
\hline & & & $2^{\text {nd }}$ & Information from specialists \\
\hline & & & $3^{\text {rd }}$ & Similar demands that were successful \\
\hline $\begin{array}{l}\text { Lack of government } \\
\text { resources }\end{array}$ & Unique & Scheduled meetings & - & Not identified \\
\hline \multirow{12}{*}{ Need for other policies } & \multirow{3}{*}{$1 \mathrm{st}$} & \multirow{3}{*}{ Scheduled meetings } & $1^{\text {st }}$ & $\begin{array}{l}\text { Data supporting the positive aspects of the } \\
\text { demand }\end{array}$ \\
\hline & & & $2^{\text {nd }}$ & Information from specialists \\
\hline & & & $3^{\text {rd }}$ & Similar demands that were successful \\
\hline & \multirow{3}{*}{ 2nd } & \multirow{3}{*}{$\begin{array}{l}\text { Non-scheduled } \\
\text { meetings }\end{array}$} & $1^{\text {st }}$ & $\begin{array}{l}\text { Data supporting the positive aspects of the } \\
\text { demand }\end{array}$ \\
\hline & & & $2^{\text {nd }}$ & Information from specialists \\
\hline & & & $3^{\text {rd }}$ & Similar demands that were successful \\
\hline & \multirow{3}{*}{$3 \mathrm{rd}$} & \multirow{3}{*}{$\begin{array}{l}\text { Lectures, seminars, } \\
\text { workshops and } \\
\text { public hearings }\end{array}$} & $1^{\text {st }}$ & $\begin{array}{l}\text { Data supporting the positive aspects of the } \\
\text { demand }\end{array}$ \\
\hline & & & $2^{\text {nd }}$ & Similar demands that were successful \\
\hline & & & $3^{\text {rd }}$ & Information from specialists \\
\hline & \multirow{3}{*}{4 th } & \multirow{3}{*}{$\begin{array}{l}\text { Contact through } \\
\text { phone, email and } \\
\text { social networks }\end{array}$} & $1^{\text {st }}$ & $\begin{array}{l}\text { Data supporting the positive aspects of the } \\
\text { demand }\end{array}$ \\
\hline & & & $2^{\text {nd }}$ & Information from specialists \\
\hline & & & $3^{\text {rd }}$ & Similar demands that were successful \\
\hline \multirow{12}{*}{ Legal impediments } & \multirow{3}{*}{$1 \mathrm{st}$} & \multirow{3}{*}{ Scheduled meetings } & $1^{\text {st }}$ & $\begin{array}{l}\text { Data supporting the positive aspects of the } \\
\text { demand }\end{array}$ \\
\hline & & & $2^{\text {nd }}$ & Information from specialists \\
\hline & & & $3^{\text {rd }}$ & Similar demands that were successful \\
\hline & \multirow{3}{*}{ 2nd } & \multirow{3}{*}{$\begin{array}{l}\text { Non-scheduled } \\
\text { meetings }\end{array}$} & $1^{\text {st }}$ & $\begin{array}{l}\text { Data supporting the positive aspects of the } \\
\text { demand }\end{array}$ \\
\hline & & & $2^{\text {nd }}$ & Information from specialists \\
\hline & & & $3^{\text {rd }}$ & Similar demands that were successful \\
\hline & \multirow{3}{*}{$3 r d$} & \multirow{3}{*}{$\begin{array}{l}\text { Contact through } \\
\text { phone, email and } \\
\text { social networks }\end{array}$} & $1^{\text {st }}$ & $\begin{array}{l}\text { Data supporting the positive aspects of the } \\
\text { demand }\end{array}$ \\
\hline & & & $2^{\text {nd }}$ & Similar demands that were successful \\
\hline & & & $3^{\text {rd }}$ & Information from specialists \\
\hline & \multirow{3}{*}{ 4th } & \multirow{3}{*}{$\begin{array}{l}\text { Lectures, seminars, } \\
\text { workshops and } \\
\text { public hearings }\end{array}$} & $1^{\text {st }}$ & $\begin{array}{l}\text { Data supporting the positive aspects of the } \\
\text { demand }\end{array}$ \\
\hline & & & $2^{\text {nd }}$ & Information from specialists \\
\hline & & & $3^{\text {rd }}$ & Similar demands that were successful \\
\hline
\end{tabular}




\section{VALIDATE THE ELEMENTS (STEP 2)}

The first public policy project used to validate the advocacy elements and their ranking was the implementation of the first exclusive route for buses, student transport and taxi transport vehicles in a large corridor linking the west to the CBD of Brasilia, the capital of Brazil.

The route has a length of eight kilometres, and it is stipulated that it can serve an area of 415,000 inhabitants. The proportion of users using public mass transport is $70 \%$ and the remaining $30 \%$ are users of private vehicles and trucks, but only $6 \%$ of vehicles on the road are buses (DFTRANS, 2011).

The second was the legislative process for approval of Law 11.705 of 2008 to increase the penalties for those who are caught driving under the influence of alcohol or any other psychoactive substance that involves addiction.

As the methodology of this work predicts, the same questionnaire from step two was applied to the stakeholders responsible for the chosen projects to validate the elements of advocacy.

Regarding the implementation project for the exclusive corridor for public passenger transport, the chosen respondent was the director of the agency responsible for its implementation, and for the second passage of the law, the respondent was the parliamentary author of the law in Congress.

The two policies studied in this work were selected due to the availability of respondents, however, only the project to provide an exclusive corridor for buses in the city of Brasilia has been tested at the stage of implementation.

This project only identified the barrier "resistance of actors" in the implementation phase, it also performed a single action "scheduled meetings" to overcome the barrier and for this three resources were used, "data supporting positive aspects of the demand, similar demands that were successful and information specialists that contribute to the demonstration of the demand legitimacy".

This indicates that the difficulty and what was performed to overcome this in the phase of implementation was provided in full as can be seen in Table 11 above.

Tables 12 and 13 shown below were prepared to compare the responses obtained in the policies studied with the ranking of the elements presented in Tables 9 and 10 and that will be the subject of analysis in this paper. 
Table 12: Comparison of the resources used in support of actions to overcome the barriers at the stage of schedule

\begin{tabular}{|c|c|c|c|c|c|}
\hline Barriers & Actions & Resources & $\begin{array}{l}\text { Occurrence } \\
\text { (Table 10) }\end{array}$ & $\begin{array}{l}\text { Occurrence } \\
\text { in Law } \\
11.705 / 2008\end{array}$ & $\begin{array}{c}\text { Occurred } \\
\text { on the } \\
\text { Bus } \\
\text { Corridor }\end{array}$ \\
\hline \multirow{13}{*}{$\begin{array}{l}\text { Resistance } \\
\text { of actors }\end{array}$} & \multirow{3}{*}{ Scheduled meetings } & $\begin{array}{l}\text { Data supporting the positive aspects of } \\
\text { the demand }\end{array}$ & $X$ & $X$ & $\mathrm{X}$ \\
\hline & & Similar demands that were successful & $\mathrm{X}$ & $\mathrm{X}$ & $\mathrm{X}$ \\
\hline & & $\begin{array}{l}\text { Information specialists that contribute to } \\
\text { the demonstration of the demand } \\
\text { legitimacy }\end{array}$ & $\mathrm{X}$ & $\mathrm{X}$ & $\mathrm{X}$ \\
\hline & \multirow{4}{*}{$\begin{array}{l}\text { Lectures, seminars, } \\
\text { workshop and } \\
\text { public hearings }\end{array}$} & $\begin{array}{l}\text { Data supporting the positive aspects of } \\
\text { the demand }\end{array}$ & $\mathrm{X}$ & $\mathrm{X}$ & - \\
\hline & & Similar demands that were successful & $\mathrm{X}$ & $\mathrm{X}$ & - \\
\hline & & $\begin{array}{l}\text { Information specialists that contribute to } \\
\text { the demonstration of the demand } \\
\text { legitimacy }\end{array}$ & $\mathrm{X}$ & $\mathrm{X}$ & - \\
\hline & & $\begin{array}{l}\text { Data supporting the positive aspects of } \\
\text { the demand }\end{array}$ & $\mathrm{X}$ & - & - \\
\hline & \multirow{3}{*}{$\begin{array}{l}\text { Contact through } \\
\text { phone, email and } \\
\text { social networks }\end{array}$} & Similar demands that were successful & $\mathrm{X}$ & $\mathrm{X}$ & - \\
\hline & & $\begin{array}{l}\text { Information specialists that contribute to } \\
\text { the demonstration of the demand } \\
\text { legitimacy }\end{array}$ & $\mathrm{X}$ & $\mathrm{X}$ & - \\
\hline & & $\begin{array}{l}\text { Data supporting the positive aspects of } \\
\text { the demand }\end{array}$ & $\mathrm{X}$ & $\mathrm{X}$ & - \\
\hline & \multirow{3}{*}{$\begin{array}{l}\text { Non-scheduled } \\
\text { meetings }\end{array}$} & $\begin{array}{l}\text { Data supporting the positive aspects of } \\
\text { the demand }\end{array}$ & $\mathrm{X}$ & - & $\mathrm{X}$ \\
\hline & & Similar demands that were successful & $\mathrm{X}$ & - & $\mathrm{X}$ \\
\hline & & $\begin{array}{l}\text { Information specialists that contribute to } \\
\text { the demonstration of the demand } \\
\text { legitimacy }\end{array}$ & $\mathrm{X}$ & - & $\mathrm{X}$ \\
\hline \multirow{2}{*}{$\begin{array}{l}\text { Need for } \\
\text { other } \\
\text { policies }\end{array}$} & \multirow[t]{2}{*}{ Scheduled meetings } & $\begin{array}{l}\text { Data supporting the positive aspects of } \\
\text { the demand }\end{array}$ & $\mathrm{X}$ & - & $\mathrm{X}$ \\
\hline & & Similar demands that were successful & $\mathrm{X}$ & - & - \\
\hline
\end{tabular}


Table 13: Comparison of the resources used in support of actions to overcome the barriers at the stage of development of options

\begin{tabular}{|c|c|c|c|c|c|}
\hline Barriers & Actions & Resources & $\begin{array}{l}\text { Occurrence } \\
\text { (Table 11) }\end{array}$ & $\begin{array}{l}\text { Occurrence } \\
\text { in Law } \\
11.705 / 2008\end{array}$ & $\begin{array}{l}\text { Occurred } \\
\text { on the } \\
\text { Bus } \\
\text { Corridor }\end{array}$ \\
\hline \multirow{9}{*}{$\begin{array}{l}\text { Resistance of } \\
\text { actors }\end{array}$} & \multirow{3}{*}{$\begin{array}{l}\text { Scheduled } \\
\text { meetings }\end{array}$} & $\begin{array}{l}\text { Data supporting the positive aspects of the } \\
\text { demand }\end{array}$ & $\mathrm{X}$ & $\mathrm{X}$ & $\mathrm{X}$ \\
\hline & & Similar demands that were successful & - & $\mathrm{X}$ & $\mathrm{X}$ \\
\hline & & $\begin{array}{l}\text { Information from specialists that contribute } \\
\text { to the demonstration of the demand } \\
\text { legitimacy }\end{array}$ & - & $\mathrm{X}$ & $\mathrm{X}$ \\
\hline & \multirow{3}{*}{$\begin{array}{l}\text { Lectures, } \\
\text { seminars, } \\
\text { workshop } \\
\text { and public } \\
\text { hearings }\end{array}$} & $\begin{array}{l}\text { Data supporting the positive aspects of the } \\
\text { demand }\end{array}$ & $\mathrm{X}$ & $\mathrm{X}$ & - \\
\hline & & Similar demands that were successful & - & $\mathrm{X}$ & - \\
\hline & & $\begin{array}{l}\text { Information from specialists that contribute } \\
\text { to the demonstration of the demand } \\
\text { legitimacy }\end{array}$ & - & $\mathrm{X}$ & - \\
\hline & \multirow{3}{*}{$\begin{array}{l}\text { Contact } \\
\text { through } \\
\text { phone, email } \\
\text { and social } \\
\text { networks }\end{array}$} & $\begin{array}{l}\text { Data supporting the positive aspects of the } \\
\text { demand }\end{array}$ & - & $\mathrm{X}$ & - \\
\hline & & Similar demands that were successful & - & $\mathrm{X}$ & - \\
\hline & & $\begin{array}{l}\text { Information from specialists that contribute } \\
\text { to the demonstration of the demand } \\
\text { legitimacy }\end{array}$ & - & $\mathrm{X}$ & - \\
\hline
\end{tabular}

\section{CONCLUSIONS}

The tables show two different situations, analysing Table 12 verifies that all elements, barriers, actions and resources found in the two policies were included in the proposal, i.e. a $100 \%$ predictive power, actually occurred also in the deployment phase, but looking at the comparison in Table 13 such probability was not repeated with respect to the elements "actions and resources to support actions".

In the second phase of the Policy Cycle, develop options, only one barrier, "resistance of actors" was identified, the two objectives of the projects studied. The element "actions" for such a barrier was predicted, with the occurrence of three in the evaluation of the second stage of the method of this work, which can be seen in Table 10, the assessment made on public transport operation of the project was found of the three, "schedule meetings" so achieving the total forecast of occurrence. In the project to approve the legislation three actions were used to overcome the barrier, one of which, "contact by phone, e-mail and social networks", did not appear in the forecast. Thus, the proposal predicted 2 of 3 occurrences.

For the element "resources to support actions", for the transport operation the level forecast was 33\% and for the adoption of the law 22\%. It may appear that the project for the approval of the law possessed worse results than the other project, such an occurrence can be explained by the fact that the eight projects used to compile Tables 9, 10 and 11 were just a case of legislating.

Even with these results for this element the level of predictability in the set was high, a fact that allows the use of these tables as indicators and to act so that we can achieve goals in the implementation of public policies. 
The fact that these tables have been presented in this work with the ranking of elements enables stakeholders who are favourable to the demand to see which actions and resources should be given priority in choosing to mount an action strategy.

The method followed here for the assembly of the elements' occurrences in the tables allows the inclusion of new information in the analysis of new public policy projects and consequent updating of Tables 9, 10 and 11, which could improve predictions for the analysis of a new project involving legislation approval.

\section{References}

Azevedo, M. A. (2003) Advocacy em Rede. Available in: www.ip.usp.br/laboratorios/lacri/advocacy.doc. Accessed in September 2007.

Breláz, G. and Alves, M. A. (2011) Deliberative democracy and advocacy: Lessons from a comparative perspective. Canadian Journal of Administrative Sciences, 28, 202-216.

Christoffel, K. K. (2000) Public health advocacy: Process and product. American Journal of Public Health, 90 (5), 722-726.

Dye, T. R. (2009) Mapeamento dos modelos de análise de política públicas. In: Heidemann, F. G. and Salm, J. F. (eds). Políticas Públicas e Desenvolvimento: Bases Epistemológicas e Modelos de Análise. Brasília, Brazil. Editora UnB.

Efroymson, D. (2006) Using media and research for advocacy: Low cost ways to increase success. Available at: www.healthbridge.ca/assets/images/pdf/Using\%20Media\%20and\%20Research\%20for\%20Advocacy\%20low\% 20cost\%20ways\%20to\%20increase\%20success\%20June\%202006.pdf. Accessed in October 2010.

Feix, V. (2004) Por uma política pública nacional de acesso à justiça. Estudos Avançados, São Paulo, Brazil, no. 51, p. 219-224.

Gibson, T. A. (2010) The limits of media advocacy. Communication, Culture \& Critique 3, 44-65.

Gomm, M., Lincoln, P., Pikora T., and Giles-Corti (2006) Planning and implementing a community-based public health advocacy campaign: a transport case study from Australia. Health Promotion International, 21 (4), $284-$ 292.

Gordon, G. (2002) Advocacy toolkit: Understanding advocacy. Available at: http://tilz.tearfund.org/webdocs/Tilz/Roots/English/Advocacy\%20toolkit/Advocacy\%20toolkit_E_FULL\%20DO C_Parts\%20A\%2BB.pdf. Accessed in August 2010.

Han, S. S. (2010) Managing motorization in sustainable transport planning: the Singapore experience. Journal of Transport Geography, 18, 314-321.

Huitema, D. and Meijerink, S. (2010) Realizing water transitions: the role of policy entrepreneurs in waterpolicy change. Ecology and Society 15 (2), 26. [online] URL: http://www.ecologyandsociety.org/vol15/iss2/art26/

Ieromonachou, P., Potter, S. and Warren, J. P. (2007) A strategic niche analysis of urban road pricing in the UK and Norway. EJTIR, 7 (1), 15-38.

Kelly, L. (2002) International advocacy: Measuring performance and effectiveness. Available at: http://portals.wi.wur.nl/files/docs/ppme/measuring_performance_effectiveness_advocacy.pdf. Accessed on 3 July 2009.

Libardoni, M. (2000) Fundamentos Teóricos e Visão Estratégica da Advocacy. Available at: http://www.periodicos.ufsc.br/index.php/ref/article/viewFile/11936/11202. Accessed on September 2010.

Lindblom, C. E. (1982) 0 processo de decisão política. Brasília, Brazil. Ed. UnB.

Mansfield, C. (2010) Monitoring \& evaluation of advocacy campaigns: Literature review. Available at: www.ealliance.ch/fileadmin/user_upload/docs/Advocacy_Capacity/2011/11._EAA_M_E_Literature_Review.pdf. Accessed in March 2011.

May, A. D., Jarvi-Nykanen, T., Minken, H., Ramjerdi, F., Matthews, B., and Monzón A. (2001) Cities' decision-making requirements. Available in: www.ivv.tuwien.ac.at/fileadmin/mediapoolverkehrsplanung/Diverse/Forschung/International/PROSPECTS/pr_del_1.pdf. Accessed in November 2011.

Morais, A. C. (2012) Projetos de infraestrutura de transportes: Inserção efetiva na agenda governamental. 
Doctoral Thesis. Universidade de Brasília, Brasília, Brazil.

Negarendeh, R., Oskouie, F., Ahmadi, F., Nikravesh, M. and Hallberg, I. R. (2006) Patient advocacy: Barriers and facilitators. BMC Nursing. 5 (3).

Nukuro, E. (2000) The lobbying process and building advocacy networks. Available at: http://pt.scribd.com/doc/35678252/The-Lobbying-Process-and-Building-Advocacy-Networks. Accessed in April 2009.

O’Flynn, J. (2009) The cult of collaboration in public policy. The Australian Journal of Public Administration, 68 (1), 112-116.

Palma, A. and Lindsey, R. (2006) Modelling and evaluation of road pricing in Paris. Transport Policy, 13 (2), , 115126.

Peterman, W. (2004) Advocacy vs. collaboration: Comparing inclusionary community planning models. Community Development Journal, 39 (3), 266-276.

Souza, C. (2006) Políticas públicas: Revisão da literatura. Sociologia, 8 (16), 20-45.

Souza, A. I. J., Althoff, C. R., Ribeiro, E. M. and Elsen I. (2006) Construindo movimento para o fortalecimento da família. Família. Saúde Desenvolvimento. 8 (3), 265-272.

Subaris, J. (2006) Definición del problema. Relevancia pública y formación de la agenda de actuación de los poderes públicos. In: Saravia, E. and Ferrarezi, E. Políticas Públicas; Coletânea. Brasília: ENAP; volume 1.

Thackeray, R. and Hunter, M. (2010) Empowering youth: Use of technology in advocacy to affect social change. Journal of Computer-Mediated Communication, 15, 575-591.

Transportes Urbanos do Distrito Federal (DFTRANS) (2011) Faixa exclusiva da EPNB comprova eficiência e reduz tempo de viagem dos ônibus. Available at: http://www.dftrans.df.gov.br/003/00301009.asp?ttCD_CHAVE=162435. Accessed in June 2012.

Ubbels, B. and Verhoef, E. (2006) Acceptability of road pricing and revenue use in the Netherlands. European Transport, 32, 68-94. 